doc. dr. sc. Bojana Olgić Draženović

Ekonomski fakultet Sveučilišta u Rijeci, Rijeka, Republika Hrvatska bojana.olgic.drazenovic@efri.hr

red. prof. dr. sc. Mario Pećarić

Ekonomski fakultet Sveučilišta u Rijeci, Rijeka, Republika Hrvatska mpecaric@efst.hr

Stella Suljić, dipl. oecc.

Ekonomski fakultet Sveučilišta u Rijeci, Rijeka, Republika Hrvatska stella.suljic@efri.hr

\title{
DETERMINANTE RAZVOJA INSTITUCIONALNIH INVESTITORA U NOVIM ZEMLJAMA ČLANICAMA EU
}

Stručni rad

\section{Sažetak}

Institucionalni investitori, kao financijske institucije koje najviše ulažu u utržive vrijednosne papire, uvelike doprinose razvoju financijskog tržišta na strani potražnje. Fenomen rasta institucionalnih investitora posebno je važan za financijska tržišta novih zemalja članica EU uključujući i Republiku Hrvatsku, koja evoluiraju i poprimaju konfiguraciju zrelih financijskih sustava. Specifično, najveći utjecaj na oblikovanje financijskih sustava novih zemalja članica EU imale su reforme vlasničkih struktura i sustava mirovinskog osiguranja odnosno demografske promjene povezane s poteškoćama državnih, međugeneracijskih mirovinskih sustava. Cilj rada je ukazati na determinante i pokazatelje razvoja najvažnijih institucionalnih investitora odnosno investicijskih fondova, mirovinskih fondova $i$ društava za osiguranje u odabranim novim zemljama članicama EU. Metode privatizacije izdavanjem dionica vodile su povećanju ponude na tržištima kapitala, dok se je utjecaj mirovinskih reformi manifestirao u jačanju potražnje za vrijednosnim papirima.

Ključne riječi: institucionalni investitori, mirovinski fondovi, investicijski fondovi, društva za osiguranje, mirovinska reforma

JEL: G22, G23 


\section{UVOD}

Jedna od ključnih promjena u evoluciji financijske strukture vezana je za razvoj institucionalnih investitora odnosno snažan pomak od individualizirane štednje ka institucionaliziranom investiranju.

Fenomen rasta institucionalnih investitora posebno je važan za financijske sustave novih zemalja članica EU koja se razvijaju i poprimaju konfiguraciju sličnu onima u zemljama «zrele» tržišne ekonomije. Udio aktive institucionalnih investitora $\mathrm{u}$ financijskim sustavima novih zemalja članica EU posljednjih godina raste, ali niska likvidnost domicilnih tržišta kapitala uvelike ograničava njihovu uspješnost i daljnji razvoj.

Nakon društvenih, političkih i ekonomskih transformacija 1990-tih godina navedene zemlje započele su sa cijelim nizom reformi usmjerenih na makroekonomsku stabilnost, liberalizaciju, restrukturiranje i privatizaciju te pravne i institucionalne reforme. Potreba za uspostavom efikasnih financijskih sustava prepoznata je kao jedan od prioriteta tranzicijskog procesa. U tom smislu, razvojni put financijskih tržišta i institucija u odvijao se pod jedinstvenim i specifičnim okolnostima. Financijski razvoj nije bio određen samo restrukturiranjem postojećih bankovnih institucija, već i izgradnjom prethodno nepostojećih (neaktivnih) dijelova financijskog sustava.

Najveći utjecaj na oblikovanje financijskih tržišta i institucija novih zemalja članica EU imale su reforme vlasničkih struktura i sustava mirovinskog osiguranja. Metode privatizacije izdavanjem dionica vodile su povećanju ponude na tržištima kapitala, dok se je utjecaj mirovinskih reformi manifestirao u jačanju potražnje za vrijednosnim papirima.

$\mathrm{U}$ radu se analizira koncept institucionalnih investitora i determinante njihova razvoja u novim zemljama članicama EU. Evolucijski put mirovinskih fondova, društava za osiguranje i investicijskih fondova sagledan je i sa stajališta temeljnih poticajnih mjera i procesa u kontekstu strukturnih reformi na primjeru odabranih novih zemalja članica i to Češke, Mađarske, Poljske Slovačke, Slovenije i Hrvatske. Odabrane zemlje su usporedivih karakteristika u smislu sličnog povijesno-političkog razvoja, ekonomske strukture, usporedivih makroekonomskih pokazatelja te sličnog tijeka razvoja tržišta kapitala i financijskih institucija. 


\section{UTJECAJ SNAGA PONUDE I POTRAŽNJE NA RAST I RAZVOJ INSTITUCIONALIZIRANE ŠTEDNJE}

Institucionalni investitori su specijalizirane financijske institucije koje sakupljaju, okrupnjuju i upravljaju štednjom malih investitora ulažući je u različite investicijske oblike u skladu s definiranim, specifičnim ciljevima kao što su prihvatljivi rizik, maksimizacija povrata i dospijeće potraživanja (Davis, Steil, 2001, 12). Sagledavajući širi kontekst, važnost institucionalnih investitora ogleda se u podizanju efikasnosti financijskog sustava (Iorgova, Ong, 2008; Davis, Steil, 2001). Oni osiguravaju bolje investicijske mogućnosti i efikasnije kanale za alociranje ekonomskih resursa i kroz prostor i vrijeme. Od širokog spektra institucionalnih investitora posebno se ističu tri vrste financijskih institucija odnosno mirovinski fondovi, društva za osiguranje i investicijski fondovi. ${ }^{1}$

Razvoj institucionalnih investitora određen je cijelim nizom faktora ponude i potražnje koji doprinose efikasnijem izvršenju funkcija financijskog sustava. Snage ponude izvode se iz superiorne sposobnosti institucionalnih investitora u izvršavanju funkcija financijskog sustava u odnosu na direktna ulaganja u vrijednosne papire.

Kao najznačajniji faktor potražnje od utjecaja na rast institucionalne štednje posljednjih desetljeća ističu se demografske promjene povezane s poteškoćama mirovinskih sustava međugeneracijske solidarnosti i uvođenja sustava kapitalizirane štednje. Demografske promjene koje uzrokuju fenomen povećanja udjela starijeg stanovništva u ukupnoj populaciji odnosno „starenja stanovništva“, imati će dalekosežne učinke na socijalni i gospodarski razvoj odnosno na makroekonomske varijable, prije svega na agregatnu potrošnju, štednju, investicije, javne rashode i ekonomski rast. Pozitivan utjecaj porasta očekivanog životnog vijeka na udio populacije opredijeljenog za visoku razinu štednje ${ }^{2}$ istražen je u brojnim radovima (Modigliani 1966; Bloom, Caninng, Sevilla 2001) i većinom se referira na hipotezu životnog ciklusa ${ }^{3}$. Starenje stanovništva u direktnoj je vezi s koncentracijom i akumulacijom štednje stanovništva putem institucionalnih investitora. Oblici i veličina štednje pri tome prate obrazac životnog ciklusa i utječu na brzi razvoj institucionalizirane štednje.

1 Osim navedenih, tradicionalnih institucionalnih investitora, u novije vrijeme sve su više zastupljeni i alternativni institucionalni investitori kojima pripadaju fondovi rizičnog kapitala, ETF fondovi, SWF fondovi itd. U širem smislu pod institucionalnim investitorima podrazumijevaju se i banke, zaklade, leasing institucije, investicijske banke, financijske kompanije i sve financijske institucije koje upravljaju tuđom imovinom ulažući je na financijskim tržištima.

2 Najveći dio ukupne štednje odnosi se na segment populacije od 30-60 godina.

3 Hipoteza životnog ciklusa (engl. life cyclus hypothesis) podrazumijeva ujednačenu potrošnju tijekom životnog vijeka, što se ostvaruje pojačanom štednjom za vrijeme radnog vijeka i potrošnjom u starosti. Model se odnosi na navike potrošnje i štednje ljudi u ovisnosti od fazi životnog ciklusa u kojoj se nalaze. 
Tablica 1. Faktori ponude i potražnje institucionalnih investitora

\begin{tabular}{|c|c|}
\hline & Razvoj institucionalnih investitora \\
\hline Faktori ponude & $\begin{array}{c}\text { mogućnost diverzifikacije portfolija } \\
\text { rast likvidnosti } \\
\text { poboljšanje korporativne kontrole } \\
\text { jačanje procesa deregulacije }\end{array}$ \\
& $\begin{array}{c}\text { korištenje prednosti tehnološkog razvoja } \\
\text { povećana kompetitivnosti na tržištu } \\
\text { povećanja broja i oblika distribucijskih kanala }\end{array}$ \\
\hline Faktori potražnje & demografske promjene \\
& poteškoće socijalnih mirovinskih sustava \\
& rast društvenog bogatstva \\
\hline
\end{tabular}

Izvor: izradio autor prema Davis i Steil (2001)

Nepovoljne demografske tendencije sveobuhvatno utječu na nacionalne socijalne sustave. Sve je više naglašena neodrživost mirovinskih sustava međugeneracijske solidarnosti ${ }^{4}$ i potreba za uvođenjem kapitaliziranih sustava. Sveobuhvatne mirovinske reforme mijenjaju strukturu štednje u korist institucionalizacije i razvoja nebankovnog tržišta, čak i u slučaju opadanja ukupne štednje u nacionalnoj ekonomiji.

Također, nedepozitna ulaganja direktno koreliraju s obrazovanošću, bogatstvom i informiranošću stanovništva, što bolje objašnjava slabiju razvijenost institucionalnih investitora u siromašnijim i manje razvijenim zemljama (Khorana, Serves i Tufano, 2004). Neovisno o demografskim kretanjima, na rast institucionalne potražnje dodatno će utjecati i akumulacija društvenog bogatstva. S rastom raspoloživog dohotka, rasti će i udio aktive stanovništva koji se drži u dugoročnim i rizičnijim instrumentima (Davis i Steil, 2001). Wiśniewski, Kamiński i Obroniecki (2014) ističu da je razvoj institucionalnih investitora i tržišta kapitala u CEE zemljama pod značajnim utjecajem promjena i volatilnosti iz okruženja, posebno u vremenima kretanja kapitala prema konzervativnijim klasama imovine (,sigurna utočišta“).

Za post-tranzicijske ekonomije procesi privatizacije ocijenjeni su kao ključan i neophodan element podizanja efikasnosti nacionalnih ekonomija. Međutim, privatizacija može donijeti primjerene rezultate samo u interakciji s ostalim reformama, prvenstveno uspostavljanju adekvatnog institucionalnog okvira. Sličan zaključak nameće se i sagledavajući utjecaj mirovinske reforme na razvoj

4 Posljednjih dvadeset godina navedene promjene posebno su izražene u novim europskim zemljama članicama koje se suočavaju s brojnim ekonomskim problemima: rastući državni deficiti, visoki javni dug, rastuća nezaposlenost, visoka stopa umirovljenja i slično. 
financijske intermedijacije. Za razliku od prve tranzicijske faze u kojoj je naglasak bio na ubrzanoj dinamici uvođenja tržišne ekonomije, naredno razdoblje naglasilo je aktualnost konvergencije prema postignutim standardima kapitalistički najrazvijenijh zemalja. Stoga se kao poseban poticajni faktor jačanja institucionalnog kapaciteta može istaći $i$ ispunjavanje potrebnih kriterija za pridruživanje ili stjecanje kandidature tranzicijskih europskih zemalja za pridruživanje EU. Navedene zemlje intenzivno su koristile i izdavanje javnog duga na domaćim tržištima kapitala kao jednu od mjera razvoja financijskih tržišta i uravnoteženja rasta institucionalne potražnje za investicijskim mogućnostima. Od posebnog značaja za napredak u procesima jačanja tržišta kapitala i institucionalizirane štednje je poticanje financijske pismenosti široke javnosti odnosno projekti financijske edukacije. Razumijevanje problematike i mogućnosti ulaganja na navedenim financijskim tržištima i planiranje uplata za štednju za starost, izuzetno je slabo. Često korištena mjera za poticanje razvoja institucionalnih investitora i posredno tržišta kapitala je pozitivna porezna regulativa. Mnoge zemlje iz uzorka koristile su porezne olakšice (najčešće za dobrovoljnu mirovinsku štednju) čime se olakšava mobilizacija štednje stanovništva, potiče interes za navedene ulagačke opcije i uravnotežuju pretežito bankocentrični financijski sustavi.

\section{TEMELJNE KARAKTERISTIKE INSTITUCIONALNIH INVESTITORA ODABRANIH TRANZICIJSKIH ZEMALJA}

Procesi rasta i razvoja institucionalnih investitora igrali su važnu ulogu u transformaciji post-tranzicijskih zemalja u tržišne ekonomije. Posljednja dva desetljeća inicijalni napori bili su usmjereni ka dizajniranju i postizanju svih relevantnih zakonodavnih, institucionalnih i regulatornih preduvjeta za funkcioniranje financijskih sustava tranzicijskih zemalja.

Razvoj institucionalnih investitora u post-tranzicijskim zemljama možemo podijeliti na tri glavna razdoblja. Prvo razdoblje formiranja i inicijalnog razvoja institucionalnih investitora obilježilo je posljednje desetljeće 20. stoljeća. Razdoblje od 2000.-2007. godine označio je intenzivan rast institucionalnih investitora. Osim snažnog uzleta na financijskim tržištima, značajan poticajni faktor bilo je jačanje institucionalnog kapaciteta slijedom ispunjavanja potrebnih kriterija za EU. Posljednje razdoblje, nakon 2007. godine omeđeno je globalnom ekonomskom krizom. Veličina institucionalnih investitora značajno se razlikuje u promatranim zemljama i primarno je određena veličinom nacionalne ekonomije (grafikon 1). ${ }^{5}$

5 Za većinu korištenih varijabli korišteni su sekundarni podaci dostupni iz baze podataka OECD-a, baze podataka Svjetske banke (World Development Indicators, WDI). 
Grafikon 1. Aktiva institucionalnih investitora odabranih zemalja u 2015. godini (mlrd. USD)



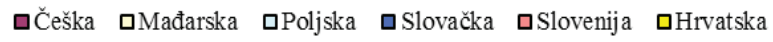

Izvor: OECD (2015)

Institucionalni investitori doprinijeli su širenju ulagačkih opcija za individualne investitore, jačanju konkurentnosti na tržištu i uravnoteženju bankocentričnih financijskih sustava.

\subsection{Mirovinski fondovi}

Tržište mirovinskih fondova najbrže je rastući segment financijskog tržišta u promatranim ekonomijama. Razlike u rastu imovine pod upravljanjem uzrokovane su početkom i prirodom reformi, rasponom investicijskih mogućnosti i specifičnom investicijskom regulativom. Vrijedi napomenuti da je kod svih zemalja snažan rast aktive mirovinskih fondova u direktnoj korelaciji s uspostavom obveznog (drugog) stupa mirovinskog sustava. Navedeno potvrđuje i grafikon 2 koji ukazuje na heterogenost zemalja u razvoju mirovinskog tržišta.

Grafikon 2. Aktiva mirovinskih fondova u BDP-u u odabranim zemljama od 1995. do 2015. godine

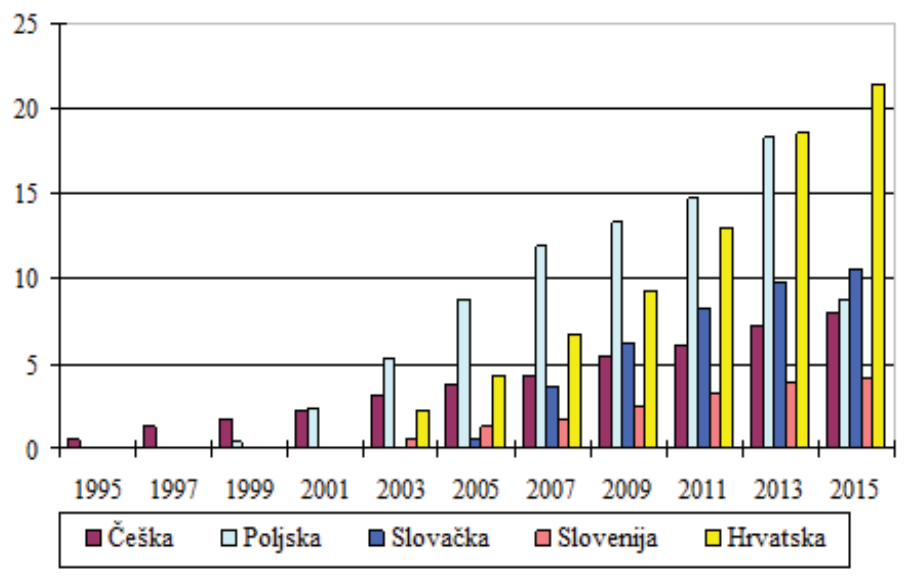

Izvor: OECD 1995.-2015. 
Najveći udio aktive u ostvarenom BDP-u ostvarile su Poljska i Mađarska, koje su ujedno i prve tranzicijske zemlje koje su krenule u sveobuhvatne mirovinske reforme krajem 90-tih godina. Slijedi ih Hrvatska, a od ostalih zemalja posebno se izdvaja Slovačka zbog ubrzanog rasta imovine od 2005. godine kada se je kao posljednja od tranzicijskih zemalja odlučila na uvođenje obvezne kapitalizirane štednje. Češka je reformirala mirovinski sustav 1994. godine kao kombinaciju niza parametarskih reformi PAYG sustava i njegovu nadopunu dobrovoljnim dopunskim mirovinskim osiguranjem. Slovenija je 2000. godine provela sveobuhvatnu mirovinsku reformu jedinstvenu među novim zemljama članicama EU. Prihvaćeni model mirovinskog sustava nije se bazirao na modelu Svjetske banke već na praksi zapadnoeuropskih zemalja i OECD-ove klasifikacije. Osim prvog, obveznog stupa (PAYG), drugi stup se odnosi na profesionalne planove koji su obvezni za određene sektore. Dobrovoljna, privatna mirovinska štednja čini treći stup, ali je odaziv vrlo slab.

Izbijanjem financijske krize javni budžeti morali su podnijeti dodatan pritisak zbog financiranja nedostatnih sredstava za isplatu mirovina, uslijed čega je došlo do preispitivanja postojećih mirovinskih sustava. Neke od zemalja odlučile su se na promjene. Mađarska je 2011. godine gotovo u potpunosti nacionalizirala 2 . stup mirovinskog osiguranja, a Poljska je iste godine značajno smanjila izdvajanja odnosno obvezne uplate $u$ mirovinske fondove i preusmjerila ih natrag $u$ prvi stup mirovinskog osiguranja (. ${ }^{6}$ Slovačka je već tri godine nakon uvođenja kapitalizirane štednje dopustila napuštanje drugog mirovinskog stupa i potpuno prebacivanje štednje u prvi stup. ${ }^{7}$

U većini zemalja dobrovoljna štednja u mirovinskim fondovima nije polučila očekivane rezultate usprkos državnim poticajima koje su uvele sve promatrane zemlje (porezne olakšice za radnike ili poslodavce). Najmanje članova u apsolutnom iznosu privukli su fondovi Slovačke, Slovenije i Hrvatske koje se izdvajaju i kao najmanje ekonomije iz uzorka s najmanje stanovnika. Iz tog razloga pokazatelj broja članova je koristan samo kao reprezentant veličine navedenih tržišta, ali ne i njihove razvijenosti. Broj članova u mirovinskim fondovima ostvaruje stabilan rast obzirom na temeljne postavke mirovinske reforme, posebno u onim zemljama koje su se odlučile na uvođenje obvezne kapitalizirane štednje.

6 Novi zakonodavni okvir iz 2011. godine smanjio je obvezna izdvajanja za drugi stup 7,3\% na 2,3\%. Tri godine kasnije građani su imali mogućnost potpunog istupanja iz sustava kapitalizirane štednje, nakon čega je u 2. stupu mirovinskog osiguranja ostalo tek $18 \%$ građana. Tijekom 2017 godine očekuje se odluka o potpunoj nacionalizaciji 2. stupa i/ili prebacivanju dijela aktive u 3. stup mirovinskog sustava.

7 Od 2012. godine u Slovačkoj su smanjene obvezne uplate stup kapitalizirane štednje s 9\% na $4 \%$ bruto plaće. Za 2017. godinu planirano je ponovno povećanje uplate u drugi stup po stopi od $0,25 \%$ godišnje, sve do ukupno $6 \%$ koji se planira dosegnuti 2024 . godine. 
Bakker i Gross (2004) naglašavaju značajan rizik portfolija mirovinskih fondova europskih tranzicijskih zemalja. Stanko (2016) emprijskim istraživanjem ukazuje na neadekvatnu konzervativnu investicijsku politiku mirovinskih fondova, koja je ublažena posljednjih nekoliko godina. Portfoliji su koncentrirani na ulaganja u nisko prinosne depozite, mali broj korporativnih vrijednosnih papira, državne obveznice i nelikvidno tržište nekretnina. Jedan od problema povezanih sa strukturom ulaganja mirovinskih fondova odnosi se na karakteristike nedovoljno razvijenih financijskih tržišta tranzicijskih zemalja. Pokazalo se da naglo rastuća imovina fondova nije uravnotežena s adekvatnom ponudom financijskih instrumenata. Navedeno je u većini zemalja dovelo do efekta „napuhavanja“ tržišta i potrebe da se ulaganja više usmjere na inozemna tržišta ili da se domaća tržišta u većoj mjeri otvore inozemnom kapitalu.

Tablica 2. Struktura ulaganja mirovinskih fondova u odabranim zemljama

\begin{tabular}{|c|c|c|c|c|c|c|c|c|c|c|}
\hline & \multicolumn{2}{|c|}{ Obveznice } & \multicolumn{2}{|c|}{$\begin{array}{c}\text { Gotovina i } \\
\text { depoziti }\end{array}$} & \multicolumn{2}{c|}{ Dionice } & \multicolumn{2}{|c|}{$\begin{array}{c}\text { Investicij- } \\
\text { ski fondovi }\end{array}$} & \multicolumn{2}{c|}{ Ostalo } \\
\cline { 2 - 12 } & $\mathbf{2 0 0 5}$ & $\mathbf{2 0 1 4}$ & $\mathbf{2 0 0 5}$ & $\mathbf{2 0 1 4}$ & $\mathbf{2 0 0 5}$ & $\mathbf{2 0 1 4}$ & $\mathbf{2 0 0 5}$ & $\mathbf{2 0 1 4}$ & $\mathbf{2 0 0 5}$ & $\mathbf{2 0 1 4}$ \\
\hline Češka & 80,3 & 87,8 & 8,2 & 8.3 & 7,4 & 0,1 & 0,0 & 1,5 & 4,0 & 2,3 \\
\hline Mađarska & 75,5 & 63,6 & 1,4 & 5.7 & 7,8 & 5,2 & 9,0 & 23,7 & 6,3 & 1,8 \\
\hline Poljska & 63,1 & 9.5 & 4,1 & 7.2 & 31,8 & 81,9 & 0,5 & 0,1 & 0,4 & 1,4 \\
\hline Slovačka & 11,2 & 68,8 & 81,8 & 16.9 & 6,2 & 1,5 & 0,0 & 12,1 & 0,7 & 0,8 \\
\hline Slovenija & 78,4 & 48,7 & 13,4 & 23.9 & 3,0 & 1,2 & 5,1 & 26,1 & 0,1 & 0,1 \\
\hline Hrvatska & 79,0 & 72,5 & 3,9 & 3,6 & 3,9 & 18,3 & 9,9 & 5,2 & 3,3 & 0,4 \\
\hline
\end{tabular}

Izvor: OECD

Najveći dio ulaganja (uz izuzetak Poljske) odnosi se na domaće državne obveznice i neaktivnu buy and hold strategiju, dok se na inozemna ulaganja odnosi manje od $10 \%$ udjela u svim promatranim zemljama. Prikazana struktura ulaganja uzrokuje visoku izloženosti domaćem tržištu i značajan politički rizik. Ujedno je državni dug izuzetno osjetljiv na monetizaciju do koje može doći uslijed inflacije i s ciljem reduciranja duga.

Portfolio mirovinskih fondova u svim odabranim zemljama odražava visoku osjetljivost na rizik, budući da je strukturiran konzervativnije i od samih limita određenim strogom zakonskom regulativom, a što je rezultiralo ponašanjem koje odudara od temeljnih premisa mirovinskih reformi. Kvantitativna ograničenja ulaganja za sve tranzicijske zemlje značila su i ograničenje poticaja razvoju 
nacionalnih tržišta kapitala koja su se trebala ostvariti uvođenjem sustava kapitalizirane štednje. Štoviše, stroga regulacija ulaganja ne potiče institucionalne investitore na postizanje viših prinosa uz istu razinu rizika, smanjuje se kompetitivnost sudionika na tržištu i usporava razvoj mirovinskih fondova. U širem kontekstu, dolazi do neefikasne alokacije kapitala i zaostajanja u ekonomskom razvoju i zaposlenosti. Vrijedi napomenuti da su kvantitativna ograničenja ulaganja opravdana u slučajevima kada fond manageri i regulatori nemaju dovoljno iskustva, a tržišta su nerazvijena i volatilna te otvorena manipulacijama. S razvojem tržišta, regulacija bi trebala postati liberalnija (Stanko 2016).

Osim investicijskih ograničenja, većina zemalja je uvela i dodatne mjere u i cilju očuvanja štednje za mirovinu. Primjerice, definirani su minimalni garantirani povrati na uložena sredstva (primjer Češke), kao i obveze fond managera za redovitom objavom performansi i tržišne vrijednosti aktive fondova (Iorgova i Ong, 2009). Navedene mjere potaknule su na ulaganja s kraćim horizontom ulaganja od optimalnih kao primjerice u Mađarskoj i Poljskoj. Navedeno je uzrokovalo fenomen „krda“ odnosno odabir slične strategije alokacije portfolija sa ciljem minimaliziranja mogućnosti ostvarenja lošijih performansi od konkurencije (Kurach i Papla, 2016, 92).

Portfelji nisu adekvatno postavljeni, ali uzrok problema može se potražiti ne samo u neadekvatno postavljenom institucionalnom okviru, već i u visokom troškovnom opterećenju sustava i vezanošću za financijski položaj države. Obzirom na navedeno kao i na dugi investicijski horizont mirovinskih fondova potrebno je regulaciju i tržišno okruženje usmjeriti ka liberaliziranju ulaganja i čvrstoj kontroli upravljanja rizicima. Dugoročno treba težiti minimiziranju uloge zakonskih limita i afirmaciji načela ,pravila razboritosti“, kao i aktivnijem nastupu ovih institucionalnih investitora kroz jačanje ulagačke komponente u rizičnije klase imovine i na tržišta izvan nacionalnih okvira. Poseban problem je i visoka koncentracija mirovinskih društava te brzi rast njihove aktive u suprotnosti sa skromnim kapacitetima nacionalnih tržišta kapitala, koja iziskuju borbu protiv netržišnih postupaka i aktivniju ulogu regulatora.

Nedostaci koji se pripisuju djelovanju mirovinskih fondova na post-tranzicijskim tržištima usmjereni su na nezadovoljavajuće performanse, visoke naknade i troškove sustava, kratak investicijski horizont ulaganja, konflikt interesa članova fonda i managementa, visoku koncentracija mirovinskih društava te neadekvatna struktura ulaganja (OECD 2014; Stanko 2016). Mirovinski segment financijskog sustava u narednim razdobljima trebao bi težiti unapređenju i otklanjanju upravljačkih i supervizorskih slabosti, jačanju konkurentnosti i nedostajućih vještina managementa (Harzberger i Watson 2007; Dimitrov 2014). 
Usprkos navedenim nedostacima, u sljedećem kratkoročnom razdoblju glavni faktori koji će determinirati rast mirovinske štednje biti će usmjereni na nezaustavljiva nepovoljna demografska kretanja te kretanje dohotka i ostalih ekonomskih performansi nacionalnih ekonomija.

\subsection{Društva za osiguranje}

Aktiva društva za osiguranje (primarno životnog osiguranja) predstavlja važan dio ulaganja na tržištu kapitala. Uz mirovinske fondove riječ je o ulaganjima s najdužim horizontom ulaganja, obično s dospijećem preko 10 godina.

Važnost osiguranja za ukupnu nacionalnu ekonomiju predstavljen je indikatorom penetracije osiguranja. Relativni udio ukupne premije osiguranja u ukupnoj ekonomskoj aktivnosti raste s porastom dohotka nacionalne ekonomije.

Dinamika penetracije ukupnog osiguranja za odabrane zemlje ukazuje na relativno niske početne vrijednosti ovog pokazatelja. Brokešova i Vachalkova (2016) kao uzroke ističu nedovoljnu financijsku pismenost, niske razine ekonomskog razvoja i monopolističko tržište osiguranja. Slovenija se ističe kao najrazvijenija zemlja iz uzorka, slijede je Češka i Poljska, dok je Hrvatska najlošije rangirana. Sve zemlje su u promatranom razdoblju ostvarile rast promatranog pokazatelja, $\mathrm{s}$ izuzetkom 2008. i 2009. godine. Navedeno razdoblje bilo je izrazito nepovoljno za osiguratelje ne samo zbog pada prihoda i porasta troškova prouzročenih globalnom financijskom krizom već i uslijed porasta potraživanja po osnovi prirodnih katastrofa.

Značaj životnog osiguranja ispod 50\% ukazuje na njegovu nedovoljnu afirmaciju u odabranim zemljama. Poljska je zemlja s najvećim udjelom životnog osiguranja dok najlošije performanse ostvaruju tržišta Slovenije i Hrvatske. Usprkos lošijem omjeru životnog i neživotnog osiguranja, Slovenija se može izdvojiti kao najrazvijenija zemlja iz uzorka sagledavajući ostale pokazatelje. Razlozi za zaostajanje ostalih zemalja nalaze se u nižem životnom standardu građana i dugogodišnjim većinskim državnim udjelima u vlasništvu društava za osiguranje (osim Poljske).

U godinama financijske krize životno osiguranje u razvijenim zemljama ostvarilo je oštar pad dok se je kod tranzicijskih zemalja iskazala znatno manja elastičnost osiguranja života. Iz navedenog proizlazi zaključak o nerazvijenom tranzicijskom tržištu osiguranja koje ne odgovara u punoj mjeri izazovima iz okruženja i ne prepoznaje životno osiguranje kao investicijski proizvod. Također, ne postoji ni adekvatna povezanost s kretanjima na tržištu kapitala. 
Grafikon 3. Penetracija osiguranja za odabrane zemlje od 1995. do 2015. godine

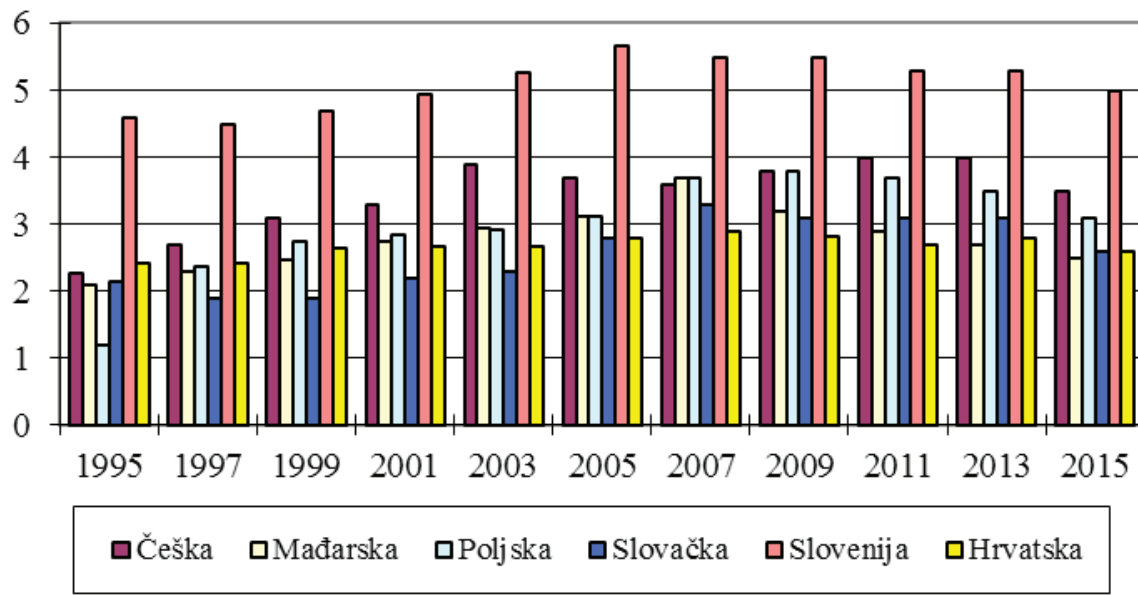

Izvor: OECD 1995.-2015.

Grafikon 4. Udio životnog osiguranja u ukupnoj premiji u odabranim zemljama od 1995-2015 g. (\%)



Izvor: OECD 1995.-2015.

Industriju osiguranja u promatranim post-tranzicijskim zemljama karakteriziraju kompozitne osiguravajuće kompanije, koje nude neživotno i životno osiguranje. Vlasništvo društva za osiguranje je uz izuzetak Slovenije, pretežito inozemno. Tržišta osiguranja su koncentrirana s blagom tendencijom pada. U svim zemljama iz uzorka udjel prvih 5 osiguranja prelazi $60 \%$. 
U sljedećem razdoblju očekuje se jačanje segmenta zdravstvenog i blagi rast životnog osiguranja. Izazovi za osiguravatelje predstavljaju napori za unapređenje profitabilnosti u okruženju izuzetno niskih troškova pribavljanja kapitala kao i uvođenje novih regulatornih zahtjeva u EU (Solvency II). Ekonomsko okruženje je i dalje volatilno, a mogućnosti štednje stanovništva, usprkos pozitivnim stopama rasta, su i dalje vrlo slabe. Najveći napredak očekuje se u dijelu novih on-line usluga usmjerenih na korisnika, koje će doprinijeti snižavanju ukupnih troškova i razvoju sofisticiranih strategija cjenovnih modela. U budućem srednjoročnom razdoblju očekuje se blagi rast tržišta osiguranja u promatranim zemljama uslijed više faktora: rasta dohotka stanovništva, eksponencijalnog rasta tehnologije, financijskog opismenjavanja stanovništva, nepovoljnih demografskih trendova, kao i sve dinamičnijeg profila korisnika osiguranja i personalizacije usluga.

\subsection{Investicijski fondovi}

Razvoj fondovske industrije u Češkoj, Slovačkoj i Hrvatskoj bio je potaknut procesom kuponske privatizacije. Privatizacijski investicijski fondovi su imali veliku ulogu u promociji tržišta kapitala, a ujedno su u navedenim zemljama imali ulogu prvih institucionalnih investitora. Ipak, nedorečenost zakona i propusti u regulativi omogućili su prostor za malverzacije i negativno obilježili ovo razdoblje. Rezultat je bila zloporaba prava manjinskih dioničara i gotovo nepostojeće korporativno upravljanje. Do kraja prvog desetljeća tranzicijskog razdoblja PIF-ovi su se transformirali u holding kompanije ili u regulirane investicijske fondove usporedo s dovršenjem regulatornog režima i institucionalne infrastrukture.

Mađarska je bila prva od promatranih tranzicijskih zemalja koja je zakonski definirala poslovanje investicijskih fondova još 1991. godine, ali ipak nije intenzivnije sudjelovala u kuponskoj privatizaciji. Zakonodavni okvir i praksa fondovske industrije danas je gotovo potpuno usklađen s regulativom EU. Razvoj investicijskih fondova u Poljskoj može se podijeliti u dvije faze. Prva je trajala od osnivanja prvog fonda 1992. godine i bila obilježena jakom ovisnošću vrijednosti neto imovine investicijskih fondova o stanju na burzi. Druga faza počela je 2000. godine kada je uvođenjem poreznih olakšica došlo do značajnog rasta imovine i bila pojačana sljedeće godine najavom o uvođenju poreza na kapitalni dobitak od $19 \%$.

Od 2000. nastupio je ubrzan rast ovih institucionalnih investitora, ali iz vrlo niske baze uz ograničenje nedostatka tradicije ulaganja u navedenu opciju ulaganja. Posljednjih 10 godina, prema ukupno prikupljenim sredstvima, dominantnu ulogu u fondovskoj industriji imaju investicijski fondovi otvorenog tipa, kao i u razvijenim zemljama. 
Grafikon 5. Udio aktive otvorenih investicijskih fondova u BDP-u za odabrane zemlje od 1995. do 2015. godine (\%)

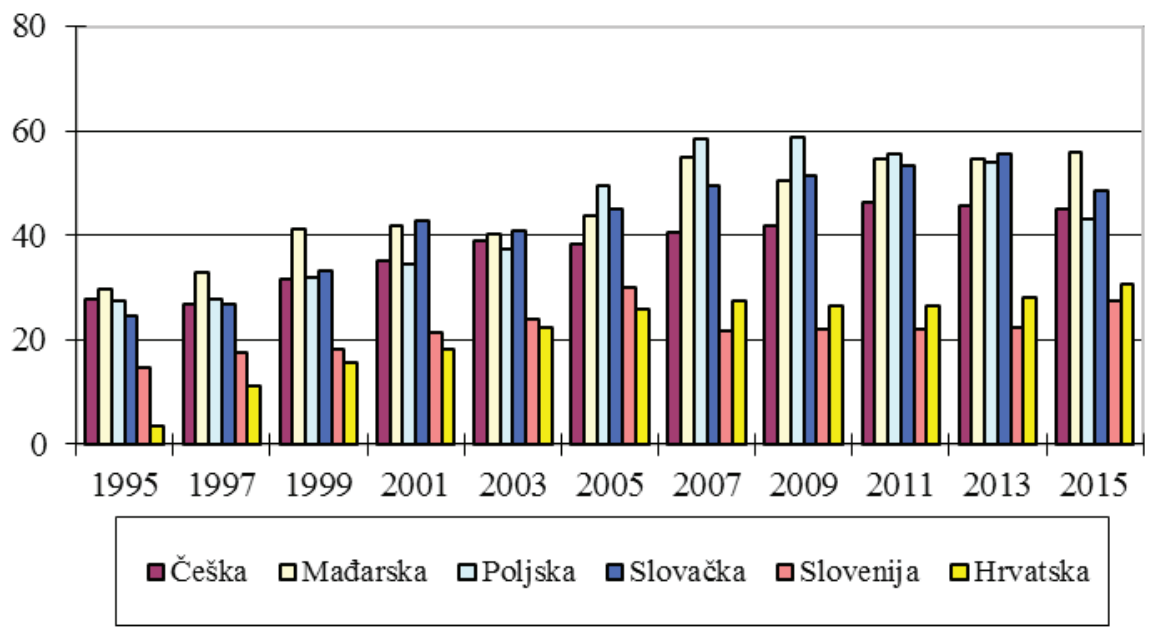

Izvor: OECD 1995.-2015.

Do 2000. godine najveći udio aktive u BDP-u iskazala su tržišta investicijskih fondova u Sloveniji, Češkoj i Hrvatskoj što korespondira s počecima djelovanja PIF-ova i procesa kuponske privatizacije. Ostale zemlje slijedile su uravnotežen i stabilan razvoj fondovske industrije koja je prekinuta globalnom financijskom krizom od 2008. godine. Od 2009. godine, u većini promatranih zemalja, bilježi se polagan oporavak tržišta i rast udjela aktive. Prema općoj gospodarskoj važnosti fondova, odnosno udjelu imovine otvorenih investicijskih fondova $\mathrm{u}$ BDP-u, Hrvatska ne zaostaje za post-tranzicijskim zemljama koje su ušle u prvi krug proširenja EU. U narednom razdoblju očekuje se razvoj inovativnih proizvoda investicijskih fondova (kao što su fondovi fondova, hedge fondovi i dr.). Postojeća literatura upućuje na veliki broj faktora o kojima ovisi budući razvoj fondovske industrije; razvoj i kvaliteta korporativnog upravljanja, regulatorni okvir, otvorenost ekonomije, razvoj i stabilnost domaćih tržišta kapitala i ekonomski rast (Huij, Post 2011; Lemeshko, Rejnuš 2015).

\section{ZAKLJUČAK}

Financijski sustavi novih zemalja članica EU prije tranzicijskog procesa postojali su u formi krutog kreditno-distributivnog sustava financiranja uz veliku ulogu bankovnog sektora. Takva struktura onemogućavala je razvitak diverzificiranih tokova i oblika prikupljanja kapitala. Tržišno orijentirane reforme u navedenim zemljama posebno su naglasile značaj razvoja institucionalnih investitora 
odnosno mirovinskih fondova, investicijskih fondova i društava za osiguranje. Najvažniji procesi kojima su nove zemlje članice EU posredno stimulirale razvoj institucionalnih investitora i time potaknule potražnu stranu tržišta kapitala odnose se na procese privatizacije i reforme mirovinskih sustava. Privatizacijske reforme otvorile su mogućnost ulaganja institucionalnim investitorima, ali je njihov doprinos razvoju tržišta kapitala izostao, osobito kod investicijskih fondova. S druge strane, mirovinske reforme inicirale su značajnu potražnju za vrijednosnim papirima od strane mirovinskih fondova, ali ipak uz velika institucionalna ograničenja.

Financijski sustavi ekonomija iz uzorka u pravilu su dio malenih, otvorenih ekonomija koje su izložene visokim rizicima u globaliziranom financijskom sustavu. Ranjivost takvih financijskih sustava obilježio je i razvoj institucionalnih investitora nastupom svjetske financijske krize. Eksterni šok izravno se prenio na sve dijelove sustava, a najveći pad su podnijeli investicijski fondovi. Društva za osiguranje i mirovinski fondovi pokazali su se otpornijima na promjene u okruženju. Procesi financijske globalizacije u značajnoj mjeri utječu na ova tržišta koja i dalje doživljavaju promjene strukturne i funkcionalne prilagodbe. Uzimajući u obzir volatilnost ekonomskog okruženja, ali i očekivano povećanje štednje stanovništva poticano pozitivnim stopama rasta, za očekivati je daljnju diverzifikaciju sustava financijskog posredovanja te njihov značajniji utjecaj na gospodarski rast.

\section{LITERATURA}

1. Bakker, M.R., Gross, A. (2004), Development of Non-bank Financial Institutions and Capital Markets in European Union Accession Countries, WB Working Paper, no. 28, Washington: The World Bank, dostupno na: http:// www-wds.worldbank.org/external/default/WDSContentServer/WDSP/ IB/2004/04/06/000090341_20040406143746/Rendered/PDF/284040PAPER0WBWP028.pdf, (pogledano 10.09.2016.)

2. Beck, T., Demirgüç-Kunt, A. (2009), Financial Institutions and Markets across Countries and over Time-Data and Analysis, CentER, Department of Economics, Tilburg university, World Bank dostupno na: http://siteresources. worldbank.org/INTRES/Resources/469232-1107449512766/Financial_Institutions_and_Markets_across_Countries.pdf, (pogledano 15.01.2017.)

3. Bloom, D. E., Canning, D., Sevilla, J. (2001), Economic growth and the demographic transition, NBER Working Paper 8685, dostupno na: http:// unpan1.un.org/intradoc/groups/public/documents/apcity/unpan014333.pdf, (pogledano 01.06.2011). 
4. Brokešova, Z., Vachalkova, I. (2016), Macroeconomic environment and insurance industry development: The case of Visegrad group countries, Ekonomická revue - Central European Review of Economic Issues, 19, str. 63-72

5. Davis, E. P., Steil, B. (2001), Institutional investors, MIT Press, Cambridge

6. Dimitrov, S. (2014), Capital Pension Funds: the Changing Role in South and Eastern European Countries, Economic Alternatives, 4, str. 110-118

7. Herzberg, V., Watson, M. (2007), Economic Convergence in South-Eastern Europe: Will the Financial Sector Deliver?, SUERF, 2007/2.

8. Holzman, R., Bebczuk, R. N., Musalem, A. R. (2008), Aging Populations and Financial markets: Global Challenges and regional perspectives for Central, Eastern and Southern Europe, Expert Workshop by ERSTE Foundation, 13.-14.06.2007., Prag, dostupno na: http://www.roa.unimaas.nl/seminars/ pdf2007/holzman191007.pdf, (pogledano 12.10.2016.)

9. Huij, J., Post, J. (2011), On the performance of emerging market equity mutual funds, Emerging Markets Review, 12, 3, str. 238- 249.

10. Iorgova, S., Ong, L.L. (2008), The Capital Markets of Emerging Europe: Institutions, Instruments and Investors, International Monetary Fund, Monetary and Capital Markets Department, IMF Working paper WP/08/103, dostupno na: http:/www.imf.org/external/pubs/ft/wp/2008/wp08103.pdf, (pogledano 25.09.2016.).

11. Iwanicz-Drozdowska M., Smaga P. (2017). Development of Financial Systems in 1995-2014: A Factor Analysis. In: Jajuga K., Orlowski L., Staehr K. (eds) Contemporary Trends and Challenges in Finance. Springer Proceedings in Business and Economics. Springer, str. 125-134.

12. Khorana, A., Serves, H, Tufano, P. (2004), Explaining the size of the mutual fund industry around the world, Research working paper, London: London Business School, dostupno na: http:/gunther.smeal.psu.edu/papers/Business/457/explaining_the_size_of.pdf, (pogledano 30.10.2017)

13. Kurach, R., Papla, D. (2016), Should pension funds hedge currency risk? The case of Poland, Baltic Journal of Economics, 16, 2, str. 81-94.

14. Lemeshko, O., Rejnuš, O. (2015), Modeling the Size of the Mutual Fund Industry in Countries of Central and Eastern Europe, Financial Assets and Investing, 6, 1, str. 7-34.

15. Modigliani, F.(1966), The Life Cycle Hypothesis of Saving, the Demand for Wealth and the Supply of Capital, Social Research, 33, 2, str. 160-217

16. OECD (2014) Annual survey of investment regulation of pension funds, dostupno na: http://www.oecd.org/finance/private-pensions/annualsurveyofinvestmentregulationofpensionfunds.htm, (pogledano 15.01.2017.) 
17. Simoneti, M., Erker, I., Lukovac, G. (2003), Institutional Investors in Slovenia, Bančni Vestnik, 7-8, str. 115-128

18. Stanko, D. (2016), Analysis of the functioning of funded parts of the pension system in selected CEE countries in the context of the implemented changes, $\mathrm{u}$,,Retreat from mandatory pension funds in countries of the Eastern and Central Europe in result of financial and fiscal crisis: Causes, effects and recommendations for fiscal rules“, str. 21-46

19. Wiśniewski, P., Kamiński, T., Obroniecki, M. (2015), Sovereign wealth funds in central and eastern Europe: scope and methods of financial penetration, Financial Internet Quarterly ,e-Finanse”, 11, 1, str. 11-21 


\title{
Bojana Olgić Draženović, Ph.D.
}

Faculty of Economics University of Rijeka, Rijeka, Croatia bojana.olgic.drazenovic@efri.hr

\section{Mario Pečarić, Ph.D.}

Faculty of Economics University of Rijeka, Rijeka, Croatia mpecaric@efst.hr

Stella Suljić, dipl. oecc.

Faculty of Economics University of Rijeka, Rijeka, Croatia stella.suljic@efri.hr

\section{DETERMINANT DEVELOPMENT OF INSTITUTIONAL INVESTORS IN THE NEW MEMBER STATES}

Professional paper

\begin{abstract}
Institutional investors as financial institutions that primarly invest in marketable securities, greatly contribute to the demand side of the financial market development. The phenomenon of the growth of institutional investors is particularly important for financial markets of the new EU member countries, including Croatia, which are evolving and taking the configuration of the mature financial systems. Specifically, the greatest impact on the design of financial systems of the new EU member states had reforms of ownership structures and reforms of the pension system. Methods of privatization by issuing shares led to increase of supply in the capital markets, while the impact of pension reforms manifested in strengthening the demand side of securities. The aim of this paper is to point out the determinants of investment funds, pension funds and insurance companies in selected new EU member states.
\end{abstract}

Keywords: institutional investors, pension funds, investment funds, insurance companies, pension reform

JEL: G22, G23 